\title{
Looking beyond reperfusion
}

\begin{abstract}
Acute Myocardial Infarction is thrombotic occlusion of coronary artery and sudden stoppage of blood supply leading to death of heart muscles. The Reperfusion phase of the treatment although promising could salvage at best only $2-4 \%$ of the myocardium at 6 months and also carries the risk of reperfusion injury. Despite the best optimal reperfusion therapy, the mortality of AMI still remains $9 \%$ at one year and cardiac failure occurs in $11.0 \%$. This appeals us to look beyond reperfusion therapy, repairing or regenerating lost myocardium via cell based therapy, tissue engineering and gene therapy. Efforts are directed towards regenerating myocardium which may revolutionize the treatment of AMI. This not only will decrease the mortality but also improve long term survival and quality of life.
\end{abstract}

Keywords: myocardial infarction, reperfusion injury, myocardial salvage, regeneration
Volume 7 Issue 3 - 2016

\author{
Shah VK,' Kavita K Shalia ${ }^{2}$ \\ 'Interventional Cardiologist, Sir H. N. Reliance Foundation \\ Hospital and Research Centre, Cardiology Department, India \\ ${ }^{2}$ Scientist, Sir H. N. Medical Research Society, Sir H. N. Reliance \\ Foundation Hospital and Research Centre, India
}

\begin{abstract}
Correspondence: Kavita K Shalia, Research Scientist, Sir H. N. Hospital and Research Centre, Sir H. N Medical Research Society, 4th Floor Court House, L.T. Road, Mumbai, 400002 India, Email Kavita.shalia@rfhospital.org
\end{abstract}

Received: September 24, 2016 | Published: December 13, 2016

\section{Reperfusion}

The root cause of acute myocardial infarction (AMI) was postulated way back in in 1912 by James Herrick who proposed it to be thrombotic occlusion of the coronary artery. ${ }^{1,2}$ This hypothesis prioritized thrombolytic agents into the line of treatment which could remove thrombotic occlusion, restore blood supply to myocardium and prevent or limit the extent of myocardial damage. Hume et al in 1958 was the first to propose this treatment of acute MI based on fibrinolysis. ${ }^{3}$ By the late 1970s Reimer, Jennings et al., ${ }^{4,5}$ laid down, evidence of reperfusion therapy for the treatment of AMI. In their classical experiment a canine model was subjected to coronary occlusion. The myocardial cell death began within 15 minutes of occlusion and proceeded rapidly in a wave front from endocardium to epicardium. On releasing the occlusion within a narrow time frame $(<3-6 \mathrm{hrs})$ myocardial salvage could be achieved. The degree of salvage was inversely proportional to the duration of ischemia and occurred in a reverse wave front from epicardium to endocardium. The extent of necrosis could be modified by changing metabolic demands and varying collateral blood supply as well as the duration of occlusion. Subsequent to this finding, in 1975 Chazov et al., ${ }^{6}$ initiated the phase of reperfusion for the patients of AMI wherein thrombi were lysed by infusing streptokinase directly into the blocked coronary arteries. ${ }^{6}$ Subsequently it was also demonstrated that timely reperfusion actually salvaged severely ischemic myocardium. ${ }^{7}$ The experimental evidence however, of thrombotic occlusion in the coronary artery of AMI patients was obtained in 1980. It was a landmark study conducted by Marcus DeWood and colleagues who performed coronary angiography in the early hours of AMI and found thrombotic occlusion to be present in the coronary arteries in $87 \%$ of patients studied within 4 hours of symptom onset. ${ }^{8,9}$

A major breakthrough of this journey was by the GISSI investigators ${ }^{10}$ in 1986, who in one of the first cardiac mega-trials, demonstrated a reduction in mortality by streptokinase infused intravenously which then set fibrinolysis as routine treatment for AMI. In the absence of thrombolytic therapy, spontaneous perfusion was observed early after ST elevated MI in 15-21\% of patients at 60-90minutes after study entry. No further increases were observed within the first day. All thrombolytic regimens improved early patency rates although the speed of thrombolysis varied. The Heparin and Aspirin reperfusion therapy (HART, 1990) investigators demonstrated the importance of concomitant heparin for maximising the effect of
tPA. ${ }^{11}$ The validity of these composite patency rates generated from many studies of varying design and size including ours $(1978)^{12}$ was confirmed by a single large GUSTO (1993) angiographic study. ${ }^{13}$ The later study showed that the rates of complete (TIMI 3) perfusion at 90 minutes were $54 \%$ with accelerated tPA, 29\% with streptokinase plus subcutaneous heparin and $31 \%$ with streptokinase and IV heparin. Mortality at 30 days was lowest with TIMI 3 flow [4.4\%]; highest 8.9\% among those with absent flow and intermediate in those with partial [TIMI 2] flow [7.4\%]. GUSTO 1 convincingly demonstrated that the potential of fibrinolytic agents to save myocardium and lives depended primarily on their ability to induce early (90minutes), complete (TIMI 3 flow) and sustained coronary artery recanalization. The use of fibrinolytic therapy has since been studied extensively in more than 200,000 patients in randomised clinical trials. A pooled analysis of 58 studies ( $\mathrm{N}=14214$ angiographic observations) (1994) formed the basis for an overall profile of patency rates of several commonly used reperfusion regimens. ${ }^{14}$ Reduced dose of tissue plasminogen activator (tPA) and abciximab in combination improved patency rates further up to $91 \%$. In contrast to varying early patency with different regimens, patency rates at 3-24hours and beyond were found to be similar. Reocclusion rates were generally higher after fibrin specific therapy than after nonfibrin agents (13\%vs $8 \%$ ) especially in the absence of optimal concurrent IV heparin (1997). ${ }^{15}$ However reperfusion by thrombolysis is an "illusion" created by the imperfect barometer of the static 90 minute angiographic view of coronary patency. Clinical and experimental data clearly demonstrate a sobering deterioration of benefit derived from coronary recanalization that is not early, nor rapid with incomplete reflow, with critical residual stenosis, decreased tissue level reperfusion, diminished by cyclical patency or frank reocclusion or possibly negated by reperfusion injury. Relative and absolute contraindications to thrombolytic therapy are also frequently noted e.g. severe hypertension, recent cerebrovascular accident, recent surgery or history of gastrointestinal haemorrhage. Thus appreciation of the limitations of current thrombolytic regimens created a new window of opportunity to enhance the quality of reperfusion therapy for acute MI

The concept of catheter based reperfusion for STEMI did not truly emerge until Gru"ntzig's first description ${ }^{16}$ of percutaneous transluminal coronary angioplasty (PTCA) followed by pilot experience of Rentrop and colleagues in 1979 with balloon angioplasty to open the occluded infarct artery in 7 patients. ${ }^{17}$ Mechanical recanalization by means of primary angioplasty was first used by Meyer et al., ${ }^{18}$ and Hartzler et 
al., ${ }^{19}$ Subsequently the field of catheter based reperfusion for STEMI was developed through a series of observations and reports from multiple centres as well as randomised trials and was quickly adopted in hospitals worldwide. ${ }^{20}$ The trials of catheter based reperfusion compared with fibrinolysis showed the advantage of angioplasty and stenting over pharmacological therapy, even accounting for delays encountered in transporting the patients to PCI facilities. For many years there has been an active debate as to which reperfusion therapy is better. Cumulatively 23 randomised trials in 7739 patients showed an advantage for primary angioplasty in terms of short term reduction of mortality, reinfarction and stroke. ${ }^{21}$ Angioplasty saved 20 more lives /1000 as compared to thrombolytic therapy clearly showing the superiority of the treatment. The vast majority of these patients underwent balloon angioplasty, but in recent years the use of stenting has largely replaced balloon angiolplasty. The 1990s brought the development of novel percutaneous coronary interventions (PCIs), particularly the introduction of coronary stents, initially bare metal and later drug-eluting stents following intracoronary balloon inflation to overcome restenosis. As summarised in pooled data of nine trials for primary stenting, the results were better for reduction of reinfarction and repeat target vessel revascularization. ${ }^{22}$ Primary angioplasty may be the preferred approach in patients with extensive MI who have immediate access to a cardiac catheterisation laboratory with experienced personnel. Patients having 1) contraindication to thrombolytic therapy 2) cardiogenic shock 3 ) prior coronary bypass surgery or 4) stuttering onset of pain are candidates only for primary angioplasty. Poor candidates are those in whom undue delays in access to catheterisation laboratories facilities would be expected or those with complex coronary artery disease including left main disease or a small MI.

Boersma et al., ${ }^{23}$ have shown in a systematic evaluation of fibrinolytic therapy that when applied within the first hour of symptom onset, $65 / 1000$ patients treated were saved as compared to only 29 lives saved when given 3 hours or more after infarct onset.
Similar results were seen in the GISSI -I trial. ${ }^{10}$ Regrettably, the same studies showed that only a small fraction (3-5\%) of patients presented within this golden hour. In contrast, mechanical reperfusion restores flow almost simultaneously with its successful application. Recently, investigators in the stent versus thrombolysis for occluded coronary arteries in patients with AMI (STOP AMI) trial demonstrated that myocardial salvage index was significantly higher for angioplasty than for lysis at any interval from symptom onset and particularly so after the initial 3 hours. ${ }^{24}$

Besides early administration of therapy, complete reperfusion (TIMI III) flow in the infarct artery at 90minutes is also an important predictor of improved outcomes. Even when brisk flow is achieved with lytic therapy, substantial attrition of the benefit occurs because of intermittent patency (25\%), reocclusion (13\%) and impaired microvascular flow or no Re-flow (23\%). This concept of "illusion of reperfusion" reflects our overestimation of the actual rate of complete reperfusion induced by lytic therapy which probably occurs in only $25 \%$ of those treated. Because as compared to lytic treatment primary angioplasty is capable of achieving TIMI III flow in at least 15-35\% more patients, it is reasonable to assume that this difference in the patency rates will translate into clinical benefits. ${ }^{25}$ In a pooled analysis of 4 PAMI trials Stone et al have shown that mortality at 6 months post angioplasty with TIMI III flow was $2.6 \%$ versus $6.1 \%$ with TIMI II flow and $22.2 \%$ with TIMI I flow. ${ }^{26}$ Further pre angioplasty flow had a significant impact on the ability to achieve successful reperfusion as well as 6months mortality after angioplasty wherein success rate was $98.1 \%$ for TIMI III flow as compared to $91.5 \%$ if there was TIMI 0 flow before intervention. ${ }^{27}$ This observation becomes very important in considering strategies to facilitate primary angioplasty. Now that we have entered third decade in reperfusion therapy we can expect iterative improvements in all aspects and finally optimal outcomes and reduction in fatality and morbidity and improvement of long term survival of AMI. Table 1 depicts some important landmark trials for Reperfusion Therapy by Thrmobolysis and Angioplasty.

Table I Some Important Landmark Trials for Reperfusion Therapy

\begin{tabular}{|c|c|c|c|}
\hline & Authors/Trials & Year & Outcome \\
\hline & \multicolumn{3}{|l|}{ Reperfusion by Thrombolysis } \\
\hline I & Charzov El et al., ${ }^{6}$ & 1975 & Thrombolysis by Streptokinase in blocked arteries \\
\hline 2 & GISSI investigators ${ }^{10}$ in & 1986 & Reduction in mortality by streptokinase infused intravenously \\
\hline 3 & $\begin{array}{l}\text { The Heparin and Aspirin reperfusion } \\
\text { therapy (HART) investigators" }\end{array}$ & 1990 & The importance of concomitant heparin for maximising the effect of tPA \\
\hline 4 & GUSTO (1993) angiographic study ${ }^{13}$ & 1993 & The validity of composite patency rates \\
\hline 5 & $\begin{array}{l}\text { Granger CB, White HD, Bates ER, et al., }{ }^{14} \\
\text { (pooled analysis) }\end{array}$ & 1994 & $\begin{array}{l}\text { Formed the basis for an overall profile of patency rates of several commonly used } \\
\text { reperfusion regimens. }\end{array}$ \\
\hline 6 & $\begin{array}{l}\text { Barbagelata NA, Granger CB, Oqueli E, et } \\
\text { al., }^{15} \text { (pooled analysis) }\end{array}$ & 1997 & $\begin{array}{l}\text { Reduced dose of tissue plasminogen activator (tPA) and abciximab in combination } \\
\text { improved patency rates further up to } 91 \% \text {. }\end{array}$ \\
\hline 7 & Meyer et al., 18 & 1982 & Mechanical recanalization by means of primary angioplasty first used by \\
\hline 8 & Hartzler et al., ${ }^{19}$ & 1983 & \\
\hline 9 & Hall D, Gruentzig A., ${ }^{20}$ & 1984 & The field of Catheter based Reperfusion for STEMI \\
\hline 10 & Keeley EC, Boura JA, Grines CL., ${ }^{21}$ & 2003 & Advantage of primary angioplasty over pharmacological therapy \\
\hline
\end{tabular}

\section{Reperfusion injury}

Myocardial reperfusion reduces ischemic cell death but it can also injure the surviving myocardium. In the 1960s, well before the first human reperfusion studies were carried out, Jennings RB et al., ${ }^{28}$ and Krug et al., ${ }^{29}$ demonstrated impaired reperfusion after release of a temporary coronary occlusion. Kloner RA et al., ${ }^{30}$ reported that reperfusion caused microvascular damage with swelling of capillary endothelial cells and of myocytes, leading to what was termed the 'no reflow phenomenon. Areas of no-reflow have been found to be associated with infarct expansion in animals and a high mortality in patients. ${ }^{31}$ Myocardial reperfusion is often accompanied by myocardial injury, commonly known as lethal reperfusion injury. Indeed, in 1985, myocardial reperfusion was referred as 'a doubleedged sword. ${ }^{32}$ During the past decade, three paradoxes have been incriminated as playing a role in lethal myocardial reperfusion injury. ${ }^{33}$ (1) The calcium paradox, which raises intracytoplasmic calcium concentration, (2) the oxygen paradox, in which reperfusion raises myocardial pO2, causing the formation of toxic reactive oxidants and 
(3) the $\mathrm{pH}$ paradox, in which a physiologic $\mathrm{pH}$ is suddenly restored in the ischemic zone in which the $\mathrm{pH}$ had declined. It has been postulated that these paradoxes are involved in opening a channel in the inner mitochondrial membrane, the so-called mitochondrial permeability transition pore, and that the resultant rapid influx of calcium and reactive oxygen species through these pores damages mitochondria, which in turn fail to synthesize high energy phosphate, thereby leading to myocyte death.

Prevention of lethal myocardial reperfusion injury: The clinical value of ischemic preconditioning local or remote is useful only when the timing of the prolonged ischemia, such as that induced by cardiac surgery or a PCI is known. It is not applicable to patients with the usual AMI in whom the time when the coronary occlusion will occur is of course not known. Many interventions to prevent or diminish lethal myocardial reperfusion injury have been studied. ${ }^{34}$ Two are particularly interesting and have shown some promise, both in preclinical studies as well as in small, but intriguing proof of principle clinical trials. The first is an extension of the principle of cardiac preconditioning, in which brief cycles of alternating ischemia and reflow prior to a sustained occlusion reduce the size of the subsequent infarct. ${ }^{35}$ It has been observed that this cyclic ischemia can be induced in an organ or tissue other than the heart, yet remain cardioprotective, an intervention termed 'remote ischemic preconditioning. ${ }^{36,37}$ However, 'postconditioning' in which the cyclic periods of ischemia and reflow are begun immediately after the prolonged occlusion is relieved - has also been shown to reduce ischemic injury ${ }^{38}$ and it too can be effective when carried out remotely. ${ }^{39}$ Conditioning can also be begun during the occlusion and it is then referred to as 'perconditioning'. ${ }^{40}$ Another technique used to overcome reperfusion injury was "Aspiration thrombectomy prior to coronary stenting" to overcome reperfusion injury. However Salloum et al., ${ }^{41}$ during PCI of Saphenous Vein Grafts had demonstrated that in spite of using distal protection devices i.e. filters to capture the insoluble particulate matter, there were soluble factors which may injure the distal microvascular bed. This may explain the additional myocardial injury occurring post reperfusion therapy. A meta-analysis ${ }^{42}$ from combined experience from randomized trials suggested that the use of anti-embolic devices did not decrease early mortality or reinfarction during PCI for native vessel AMI. However, in the subsequent years, the TAPAS (Thrombus Aspiration during Percutaneous coronary intervention in Acute myocardial infarction) Trial found that aspiration improved myocardial blush scores and ST-segment resolution (STR), and also was associated with lower mortality at 1year. Compared with conventional PCI, thrombus aspiration before stenting of the infarcted artery seems to improve the 1-year clinical outcome after PCI for ST-elevation myocardial infarction. ${ }^{43}$ A Metaanalyses showed improved measures of myocardial reperfusion (TIMI flow, myocardial blush, and STR) and improved procedural outcomes (reduced no-reflow and distal embolization), and three of four trials showed reduced mortality with aspiration thrombectomy which has received a Class IIa indication with primary PCI in the recent ACC/ AHA and ESC Guidelines. ${ }^{44}$ Unanswered questions include whether there is truly a mortality benefit with aspiration, which subgroups may and may not benefit from aspiration, and whether patients with large thrombus burden are better treated with mechanical thrombectomy. ${ }^{44}$ The second is pharmacologic conditioning, in which cyclosporin A was infused intravenously just prior to balloon inflation. Following encouraging preclinical studies, Griffiths et al., ${ }^{45}$ conducted a threecenter clinical trial and showed that Cyclosporin A reduced infarct size. The mechanism of protection afforded by Cyclosporin A has been prevention of opening of the mitochondrial permeability transition pore. ${ }^{46}$ However, subsequent large randomised trials Cyclosporin and Prognosis in Acute Myocardial Infarction Patients (CIRCUS) ${ }^{47}$ and Cyclosporine A in Reperufsed Acute Myocardial Infarction (CYCLE) ${ }^{48}$ have failed to show any benefits. Another pharmacological agent was Atrial natriuretic peptide which in animal experimental studies had shown that its prior administration reduced the reperfusion injury through activation of known prosurvival signalling pathways. ${ }^{49}$ In a large clinical trial administering Carperitide (an ANP analogue) at a time of PPCI demonstrated $14.7 \%$ reduction in enzymatic MI size. ${ }^{50}$ Table 2 states trials on prevention of myocardial reperfusion injury. It has been estimated that timely reperfusion can salvage approximately $50 \%$ of severely ischemic myocardium ${ }^{51}$ and that prevention of lethal myocardial reperfusion injury should prevent the necrosis of an additional $40 \%$. If the latter is successful, it would further substantially reduce the mortality from AMI. ${ }^{33}$ Many other trials have been carried out with each modality for reducing reperfusion injury in patients presenting with STEMI. ${ }^{52}$

Table 2 Trials on Prevention of Lethal Myocardial Reperfusion Injury

\begin{tabular}{|c|c|c|c|}
\hline No. & Authors/Trials & Year & Outcome \\
\hline & \multicolumn{3}{|c|}{ Brief cycles of alternate ischemia and reflow } \\
\hline I & \multirow{3}{*}{$\begin{array}{l}\text { Murry CE et al., }{ }^{35} \\
\text { Hausenloy DJ et } \\
\text { al., }{ }^{36} \\
\text { Botker HE et al.., }{ }^{37}\end{array}$} & 1986 & Cardiac Preconditioning \\
\hline 2 & & 2008 & Remote ischaemic preconditioning \\
\hline 3 & & 2010 & \\
\hline 4 & Zhao Z-Q et al., ${ }^{38}$ & 2003 & Post Conditioning-Cardiac \\
\hline 5 & Kerendi $\mathrm{F}$ et al., ${ }^{39}$ & 2005 & Remote Post Conditioning \\
\hline \multirow[t]{2}{*}{6} & Sarmento-Leite R., ${ }^{40}$ & 1993 & Per-conditioning \\
\hline & \multicolumn{3}{|c|}{ Thrombus aspiration before stenting of the infarcted artery } \\
\hline 5 & Vlaar PJ et al., ${ }^{43}$ & 2008 & $\begin{array}{l}\text { Compared with conventional } \mathrm{PCl} \text {, seems to improve the I-year clinical outcome after PCI for ST- } \\
\text { elevation myocardial infarction }\end{array}$ \\
\hline \multirow[t]{2}{*}{6} & Brodie BR et al., ${ }^{44}$ & 2011 & $\begin{array}{l}\text { Meta-Analysis of } 4 \text { trials showed improved measures of myocardial reperfusion (TIMI flow, myocardial } \\
\text { blush, and STR) and improved procedural outcomes (reduced no-reflow and distal embolization), and } \\
\text { reduced mortality with aspiration thrombectomy }\end{array}$ \\
\hline & \multicolumn{3}{|c|}{ Pharmacological Conditioning: I. Cyclopsorin A } \\
\hline I & Piot C et al., ${ }^{46}$ & 2008 & Cyclosporin A reduced infarct size \\
\hline 2 & Cung TT et al., ${ }^{47}$ & 2015 & CIRCUS Trial -failed to show the benefit \\
\hline \multirow[t]{2}{*}{3} & Ottani F et al., ${ }^{48}$ & 2016 & CYCLE Trial-failed to show the benefit \\
\hline & \multicolumn{3}{|c|}{ Atrial Natriuretic Peptide } \\
\hline I & Kitakaze $M$ et al., ${ }^{50}$ & 2007 & Reduced reperfusion injury through activation of prosurvival signalling pathways \\
\hline
\end{tabular}




\section{Salvage of myocardium}

The goal of reperfusion therapy is to restore the full nutritive flow and salvage myocardium. However after the introduction of these two modalities of the reperfusion almost 20years ago, there is very little evidence in the reduction of long term mortality with the current established reperfusion therapies. Rapid reperfusion of the occluded arteries is of great importance in salvaging ischaemic myocardium and limiting the size of infarct. Unfortunately, myocardial necrosis starts rapidly and the "damage is done" largely before patients reach the hospital and before myocardial reperfusion at the tissue level is achieved. Congestive heart failure is the commonest cause of frequent hospitalisation after MI with $50 \%$ of the patients dying within 5years of diagnosis. Despite optimal pharmacotherapy and mechanical devices, the morbidity and mortality remains high. Left Ventricular (LV) function is the single important determinant factor for improved long term survival after an AMI. Contemporary reperfusion strategies using percutaneous interventions are shown to be associated with only modest improvements in global LV function as evidenced by $2 \%$ to $4 \%$ increase in the ejection fraction (EF) at six months after an AMI. ${ }^{24}$ Cardiac transplant seems to be an ideal option for a vast number of these patients, but due to lack of donor hearts cannot meet even a partial demand of it. Other measures like heart assist devices and pacemakers have shown not to prolong the survival and are not cost effective. Various strategies like thrombectomies and distal protection devices have been tried to improve the microvascular dysfunction that occurs after the reperfusion of myocardium but have failed to salvage the myocardium. ${ }^{41}$ A host of pharmacotherapies have failed miserably except perhaps high dose adenosine, the story for which is not completely closed. Other modalities like COOl MI, HOT MI, APEX MI and post-conditioning of MI, ${ }^{42,53}$ have not held any promise as shown by the studies. Given the less than ideal results of salvaging ischemic myocardium so far, recently a great interest has emerged in myocardial regeneration therapy.

\section{Regeneration of myocardium}

The dogma that the heart is a terminally differentiated organ incapable of self renewal has been challenged. Although the cells derived from resident cardiomyocytes or circulating cells have regenerating capacity, their ability to minimize the deleterious effects of ventricular myocardial remodelling is limited. The surviving cardiomyocytes bordering the infarct zone becomes hypertrophied as part of adaptive mechanism to compensate for the loss of myocardium. However the normal angiogenesis after the myocardial infarction is insufficient to meet the greater demands for oxygen and nutrients to prevent the apoptosis of the hypertrophied cardiomyocytes. Therefore increasing the perfusion to infarcted myocardium to enhance oxygen and nutrients through the formation of new vessels has the potential to improve the cardiac function. Thus reversal of heart failure would require not only restoration of blood supply but also replacement of myocytes. This can be achieved collectively by stem cells which will increase neoangiogenesis and also replace the lost cardiomyocytes by transdifferentiation. Since early reports in experimental models less than 10years ago, ${ }^{54-59}$ the stem cell field has made enormous advances in moving towards clinically applicable treatment options, and we are now at the dawn of a new era. These positive results gave way to clinical trials on human beings wherein transplantation of bone marrow cells (BMCs) into the target coronary artery was carried out. ${ }^{60-63}$ The results from small clinical studies suggest that therapy with adult bone marrow derived cells reduces infarct size and improves left ventricular functions and perfusion. An extensive meta analysis by Abdel Latiff A et al., ${ }^{64}$ on eighteen eligible studies ( $\mathrm{N}=999$ patients) involving adult bone marrow cells such as bone marrow nuclear cells, bone marrow mesenchymal cells and bone marrow derived circulating progenitor cells measuring the same outcomes, demonstrated that as compared to controls, bone marrow transplantation improved left ventricular ejection fraction (LVEF) (pooled difference of $3.66 \%$; $95 \%$ confidence interval CI, 1.93\% to $5.4 \%, \mathrm{P}<0.001)$; reduced infarct scar size $(-5.49 \%$; $95 \% \mathrm{CI}:-9.1 \%$ to $-1.8 \%$; $\mathrm{P}=0.003)$; and reduced left ventricular end-systolic volume (LVESV) $(-4.8 \% \mathrm{ml} ; 95 \% \mathrm{CI}-8.2$ to $-1.41 \mathrm{ml} ; \mathrm{P}=0.006)$. Further steps required were to carry out multi-centeric randomized large trials targeted to address the impact of intracoronary cell therapy on important outcomes and long term event free survival as compared to the conventional therapy. With this aim Leistener et al., ${ }^{65}$ in one of the TOPCARE interim reports and Moccetti et al., ${ }^{66}$ in a single-center, open-labelled study have reported that the improvement seen at 6 months in LV functions in ABMSC group was sustained at 24months including our report. ${ }^{67} \mathrm{An}$ analysis of 48 eligible randomized controlled trials (enrolling 2602 patients), since August 2014 have demonstrated that as compared with standard therapy, BMC transplantation improved LV ejection fraction $(2.92 \%$; $95 \%$ CI, 1.91 3.92; $\mathrm{P}<0.00001)$, reduced infarct size $(-2.25 \% ; 95 \% \mathrm{CI},-3.55$ to $-0.95 ; \mathrm{P}=0.0007)$ and $\mathrm{LV}$ end-systolic volume $(-6.37 \mathrm{~mL} ; 95 \% \mathrm{CI}$, -8.95 to $-3.80 ; \mathrm{P}<0.00001)$, and tended to reduce $\mathrm{LV}$ end-diastolic volume $(-2.26 \mathrm{~mL} ; 95 \% \mathrm{CI},-4.59$ to $0.07 ; \mathrm{P}=0.06)$. Early ( $<48$ hours) $\mathrm{BMC}$ injection after myocardial Infarction was more effective in reducing infarct size, whereas $\mathrm{BMC}$ injection between 3 and 10days proved superior toward improving systolic function. A minimum of 50million BMCs seemed to be necessary, with limited additional benefits seen with increasing cell numbers. BMC therapy was safe and improved clinical outcomes, including all-cause mortality, recurrent myocardial Infarction, ventricular arrhythmia, and cerebrovascular accident during follow-up, albeit with differences between acute myocardial Infarction and chronic ischemic heart disease subgroups. ${ }^{68}$ MSCs are considered as the most suitable candidates for cardiac cell therapy. MSCs transplantation in the myocardium after ischemic injury has been shown to be cardioprotective in animal models and clinical trials. However, the beneficial effects of MSC in humans are limited because of both poor survival and impaired function of the cells in ischemic tissue. To address these issues, a number of approaches to the modification of MSCs with the aim to improve their survival and proliferation, to reduce the immune reaction, enhance transdifferentiation, and optimize the profile of secreted paracrine factors have been tested. ${ }^{69} \mathrm{It}$ has been demonstrated that Wharton's jelly-derived mesenchymal stem cells (WJMSCs), a primitive stromal population, could integrate into ischemic cardiac tissues and significantly improve heart function. ${ }^{70,71}$ The discovery of adult cardiac stem cells (CSCs) and their potential to restore functional cardiac tissue has fuelled unprecedented interest in recent years. Over the last decade, several independent laboratories have demonstrated the utility of c-kitpositive, lineage-negative cardiac stem cells (c-kit+/Lin- resident $\mathrm{CSCs}$ ) in alleviating left ventricular dysfunction and remodeling in animal models of acute and chronic myocardial infarction. ${ }^{72}$ The first clinical trial of autologous CSCs for treatment of heart failure resulting from ischemic heart disease (Stem Cell Infusion in Patients with Ischemic cardiOmyopathy [SCIPIO]) phase I trial demonstrated no adverse effects attributable to the CSC treatment, improvement in ejection fraction at 1year $(+13.7$ absolute units versus baseline) and $30.2 \%$ reduction in infarct size, significant improvement in the New York Heart Association (NYHA) functional class and in the quality of life, as measured by the Minnesota Living with Heart failure Questionnaire. ${ }^{73}$ Another cell types have been, cardiosphere-derived cells (CDCs) as a candidate cell type for regenerative therapy post- 
MI. These heart-derived cells are stem cells in that they exhibit multilineage potential and clonogenicity, but they work primarily through indirect mechanisms. ${ }^{74} \mathrm{CDCs}$ were first used clinically in prospective, randomized, controlled CADUCEUS (CArdiosphereDerived aUtologous stem CElls to reverse ventricUlar dySfunction) trial. ${ }^{75}$ Autologous CDCs grown from endomyocardial biopsy specimens were infused via the intracoronary route in 17 patients with left ventricular dysfunction 1.5 to 3 months after MI. Intracoronary administration of autologous CDCs did not raise significant safety concerns. Preliminary indications of bioactivity include decreased scar size, increased viable myocardium, and improved regional function of infarcted myocardium at 1year post-treatment. These results, which are consistent with therapeutic regeneration, merit further investigation in future trials. Thus, cell-based clinical trials to treat MI have focused on cells derived from the bone marrow or those potentially possessing functional similarities such as cardiac progenitors isolated from heart biopsies. Any benefits provided by these cells in improving heart function, left ventricular ejection fraction, or extending life expectancy after MI have been credited mostly to paracrine effects. Functional restoration of damaged myocardium will require functional cell type with similar phenotype and characteristics of the damaged tissue that can also integrate, survive, and electrically couple to the host. Human pluripotent stem cells (hPSCs) have the ability to differentiate into multiple cell types of the adult body. hPSC-derived cardiomyocytes represent a promising target population for cell-based therapies for MI because they are scalable and the product can be defined with a specific set of release criteria. $^{76,77}$ Pluripotent stem cell-derived cardiomyocyte-based therapies have enormous potential to revolutionize the management of heart disease; expedient but careful development is needed to ensure that this potential is fully realized. ${ }^{78}$ Cardiac regenerative medicine is promising, and a number of clinical trials in humans have already shown its indisputable safety. However, many factors remain unresolved, such as cell type (bone marrow, adipose tissue-derived progenitors, induced pluripotent (iPS) cells, cardiac resident progenitors, or embryonic stem cells), stimulation of endogenous regeneration through direct reprogramming of fibroblasts into cardiomyocytes, activation of resident cardiac stem cells or induction of native resident cardiomyocytes to re-enter the cell cycle, the route of administration (intramyocardial, transendocardial, or intracoronary), and the time of optimal delivery after MI. All these strategies need to be optimized since their efficiency is low. Several multi-centre trials are on-going in an attempt to answer some of these questions and to prove true benefit in clinical and functional parameters. ${ }^{79}$ For the time of optimal delivery, a meta-analysis of trials using multiple timing of BMCs therapy revealed that 4-7days following AMI ranked better than other timing groups for improvement in LVEF or reduction of the incidence of major adverse cardiac events..$^{80}$ The limited survival and engraftment of transplanted cells due to a hostile ischemic environment is a major factor affecting its utilization. Within this environment, the majority of transplanted cells undergo apoptosis prior to participating in lineage differentiation and cellular integration. Therefore, in order to maximize the clinical utility of stem/progenitor cells, strategies must be employed to increase their adhesion, retention, and engraftment in vivo. However, preconditioning of cells or cell manipulations strategies and biomaterials can enhance stem cell survival and engraftment after transplantation. Thus, tissue engineering is also emerging as an option for cardiac regeneration. Biomaterials can incorporate or mimic extracellular function (ECM) function and enhance survival or differentiation of transplanted cells, in vivo. Biomaterials can also promote angiogenesis, enhance engraftment and differentiation, and accelerate electromechanical integration of transplanted stem cells. However, the challenges are enormous, including, selection of the optimal cell source, developing engineered matrices (biological or non-biological; biocompatible or not), establishing the cellular electromechanical coupling, promoting an efficient and stable contractile function, and ensuring functional vascularization. ${ }^{81}$ A majority of these experimental processes have only been tested in small animal models. The transposition of a fat flap over the ischemic myocardium has recently been proposed, with promising results in the swine preclinical model of MI. ${ }^{82}$ Tissueengineered, hydrogel-based Mesenchymal stem cells (MSCs) ${ }^{83}$ and endothelial progenitor cell ${ }^{84}$ therapy have been shown some promising results in re-vascularizing the ischemic myocardium and preserving ventricular function through paracrine effects. ${ }^{85}$ Table 3 presents recent cell based clinical trials for cell based therapies of regeneration of myocardium. A new avenue being explored is gene therapy, an emerging multidisciplinary field that identifies key signalling pathways, and creates new technologies and novel vector constructs. ${ }^{86}$ Different routes of administration and viral vectors have been tested in small and large animal models with encouraging results. ${ }^{87,88}$ Preliminary clinical trials have been conducted for delivering AAV1SERCA $2^{89}$ or AD-HGF ${ }^{90}$ through intracoronary infusion, and have reported benefits in patients with severe heart failure.

Table 3 Recent Cell Based Clinical Trials for Cell based therapies for Regeneration of Myocardium

\begin{tabular}{|c|c|c|c|c|}
\hline No. & Authors/Trials & Year & Type of Cells & Outcome \\
\hline I & $\begin{array}{l}\text { Leistner DM et } \\
\text { al., }{ }^{65}\end{array}$ & 2011 & $\begin{array}{l}\text { circulating }(\mathrm{CPC}) \text { or } \\
\text { bone marrow-derived } \\
\text { progenitor cells (BMC) }\end{array}$ & TOPCARE-AMI -5 year follow-up favourable effects on LV function \\
\hline 2 & $\begin{array}{l}\text { Moccetti T et } \\
\text { al., } 66\end{array}$ & 2012 & $\begin{array}{l}\text { Bone marrow derived } \\
\text { mononuclear cells (BM- } \\
\text { MNC) }\end{array}$ & $\begin{array}{l}\text { Stem Cell Transplantation in Ischaemic Myocardium Study-5 year follow-up- } \\
\text { sustained improvement of left ventricular function }\end{array}$ \\
\hline 3 & Shah VK et al., ${ }^{67}$ & 2014 & BM-MNC & $\begin{array}{l}2 \text { Year Follow-up, better clinical course in stem cell therapy group as } \\
\text { compared to patients without this therapy at } 24 \text { months follow-up. }\end{array}$ \\
\hline 6 & Afzal MR et al., ${ }^{68}$ & 2015 & $\begin{array}{l}\text { An analysis of } 48 \text { eligible } \\
\text { randomized controlled } \\
\text { trials (enrolling 2602) } \\
\text { of BMC transplantation } \\
\text { patients), }\end{array}$ & $\begin{array}{l}\text { BMC therapy was safe and improved clinical outcomes, including all-cause } \\
\text { mortality, recurrent myocardial Infarction, ventricular arrhythmia, and } \\
\text { cerebrovascular accident during follow-up, albeit with differences between } \\
\text { acute myocardial Infarction and chronic ischemic heart disease subgroups }\end{array}$ \\
\hline 4 & $\begin{array}{l}\text { Bolli } R \text { et al.. } \\
\text { SCIPIO Trial }\end{array}$ & 2011 & Cardiac Stem Cells & Improvement in ejection fraction and reduction in infarct size \\
\hline 5 & $\begin{array}{l}\text { Malliaras K et al. } \\
\text { (CADUCEUS), }\end{array}$ & 2014 & $\begin{array}{l}\text { Cardiosphere-derived } \\
\text { cells }\end{array}$ & $\begin{array}{l}\text { Decreased scar size, increased viable myocardium, and improved regional } \\
\text { function of infarcted myocardium at I year post-treatment. }\end{array}$ \\
\hline
\end{tabular}




\section{Conclusion}

While current strategies are not enough to salvage the myocardium physicians will have to come out of their mind set of restricting their use to reperfusion modalities and increased use of antithrombotic, anticoagulants and devices to improve the salvage of myocardium. They have to revolutionary think about newer ways which has been elusive in the last twenty years. Every attempt must be made to optimize reperfusion, prevent reperfusion injuries and work on various fronts for regenerating the new myocardium.

\section{Acknowledgements}

Authors would like to acknowledge Sir H. N. Hospital and Medical Research Society for carrying out regeneration work in acute myocardial infarction.

\section{Conflicts of interest}

Author declares there are no conflicts of interest.

\section{Funding}

None.

\section{References}

1. Herrick JB. Landmark article (JAMA 1912). Clinical features of sudden obstruction of the coronary arteries. By James B. Herrick. JAMA. 1983; 250(13): 1757-1765.

2. Brauwald E. Evolution of the management of AMI: a 20th century saga. Lancet. 1998;352(9142):1771-1774.

3. Hume R. Fibrinolysis in myocardial infarction. $\mathrm{Br}$ Heart J. 1958;20(1):15-20.

4. Reimer KA, Jenneigs RB, Lowe, et al. The wave front phenomenon of myocardial ischemic cell death, I: myocardial infarct size vs duration of coronary occlusion in dogs. Circulation. 1977;56(5):786-794.

5. Reimer KA, Jennings RB. The wavefront phenomenon of myocardial ischemic cell death, transmural progression of necrosis within the framework of ischemic bed size [myocardium at risk] and collateral flow. Lab Invest. 1979;40(6):633-644.

6. Chazov EI, Matveeva LS, Mazaev AV, et al. Intracoronary administration of fibrinolysin in acute myocardial infarction. Ter Arkh. 1976;48(4):8-19.

7. Markis JE, Malagold M, Parker JA, et al. Myocardial salvage after intracoronary thrombolysis with streptokinase in acute myocardial infarction: assessment of intracoronary thallium-201. $N$ Engl J Med. 1981;305:777-782.

8. DeWood MA, Spores J, Notske R, et al. Prevalence of total coronary occlusion during the early hours of transmural myocardial infarction. $N$ Engl J Med. 1980;303(16):897-902.

9. DeWood MA, Notske RN, Hensley GR, et al. Intraaortic balloon counterpulsation with and without reperfusion for myocardial infarction shock. Circulation. 1980;61(6):1105-1112.

10. Gruppo Italiano per lo Studio della Streptochinasi nell'Infarto Miocardico (GISSI). Effectiveness of intravenous thrombolytic treatment in acute myocardial infarction. Lancet. 1986;1(8478):397-402.

11. Hsia J, Hamilton WP, Kleiman N, et al. A comparison between heparin and low-dose aspirin as adjunctive therapy with tissue plasminogen activator for acute myocardial infarction. Heparin-Aspirin Reperfusion Trial (HART) Investigators. N Engl J Med. 1990;323(21):1433-1437.

12. Shah VK, Daruwala DF, Karnik RD. Coronary artery recanalisation following IV Urokinase therapy. $J$ Assoc Physicians India. (1978);35(1):23.
13. The GUSTO Investigators. An International randomised trial comparing four thrombolytic strategies for acute myocardial infarction. $N$ Engl $J$ Med. 1993;329(10):673-682.

14. Granger CB, White HD, Bates ER, et al. Pooled analysis of areterial patency and Left Ventricular function after intravenous thrombolysis for acute myocardial infarction. Am J of Cardiol. 1994;74(12):1220-1228.

15. Barbagelata NA, Granger CB, Oqueli E, et al. TIMI grade 3 flow and reocclusion artery intravenous thrombolytic therapy: a pooled analysis. Am Heart J. 1997;133(3):273-282.

16. Gruntzig A, Schneider HJ. The percutaneous dilatation of chronic coronary stenoses-experiments and morphology. Schweiz Med Wochenschr. 1977;107(44):1588.

17. Rentrop KP, Blanke $\mathrm{H}$, Karsch $\mathrm{KR}$, et al. Initial experience with transluminal recanalisation of recanalised occluded infarct related artery in AMI. Clin Cardiol. 1979;2(2):92-105.

18. Meyer J, Merx W, Schweizer P, et al. Selective intracoronary lysis and transluminal coronary dilation as an immediate measure in acute myocardial infarct. Verh Dtsch Ges Herz Kreislaufforsch. 1982;48:157-165.

19. Hartzler GO, Rutherford BD, McConahay DR, et al. Percutaneous transluminal coronary angioplasty with and without thrombolytic therapy for treatment of acute myocardial infarction. Am Heart J. 1983;106(5 Pt 1):965-973.

20. Hall D, Gruentzig A. Percutaneous transluminal coronary angioplasty: current procedure and future direction. AJR Am J Roentgenol. 1984;142(1):13-16.

21. Keeley EC, Boura JA, Grines CL. Primary angioplasty versus intravenous thrombolytic therapy for acute myocardial infarction. A quantitative review of 23 randomised trials. Lancet. 2003;361(9351):13-20.

22. Nordmann AJ, Bucher H, Hengstler P, et al. Primary stenting versus primary balloon angioplasty for treating acute myocardial infarction. Cochrane Database Syst Rev. 2005;(2):CD005313.

23. Boersma E, Maas AC, Deckers JW, et al. Early thrombolytic treatment in acute myocardial infarction: Reappraisal of golden hour. Lancet. 1996;348(9030):771-775.

24. Hall D, Gruentzig A. Coronary stenting plus platelet glycoprotein IIb/ IIIa blockade compared with tissue plasminogen activator in acute myocardial infarction. Stent versus Thrombolysis for Occluded Coronary Arteries in Patients with Acute Myocardial Infarction Study Investigators. N Engl J Med. 1984;343(6):385-391.

25. Lincoff AM, Topol EJ. Illusion of reperfusion. Does anyone achieve optimal reperfusion during acute myocardial infarction? Circulation. 1993;88(3):1361-1374.

26. Stone GW, Grines CL, Browne KF, et al. Predictors of in-hospital and 6-month outcome after acute myocardial infarction in the reperfusion era: the Primary Angioplasty in Myocardial Infarction (PAMI) trial. $J$ Am Coll Cardiol. 1995;25:370-377.

27. Stone GW, Grines CL, Cox DA, et al. Controlled Abciximab and Device Investigation to Lower Late Angioplasty Complications (CADILLAC) Investigators. Comparison of angioplasty with stenting, with or without abciximab in acute myocardial infarction. New Engl J Med. 2002;346(13):957-966.

28. Jennings RB, Sommers HM, Smyth GA, et al. Myocardial necrosis induced by temporary occlusion of a coronary artery in the dog. Arch Pathol. 1960;70:68-78.

29. Krug A, Du Mesnil de Rochemont, Korb G. Blood supply of the myocardium after temporary coronary occlusion. Circ Res. 1966;19(1):57-62.

30. Kloner RA, Ganote CE, Jennings RB. The "no-reflow" phenomenon after temporary coronary occlusion in the dog. $J$ Clin Invest. 1974;54(6):1496-1508. 
31. Ndrepepvka G, Tiroch K, Fusaro M, et al. 5-year prognostic value of no-reflow phenomenon after percutaneous coronary intervention in patients with acute myocardial infarction. $J$ Am Coll Cardiol. 2010;55(21):2383-2389.

32. Braunwald E, Kloner RA. Myocardial reperfusion: a double-edged sword? J Clin Invest. 1985;76(5):1713-1719.

33. Yellon DM, Hausenloy DJ. Myocardial reperfusion injury. $N$ Engl $J$ Med. 2007;357(11):1121-1135.

34. Schwartz Longacre L, Kloner RA, Arai AE, et al. New horizons in cardioprotection: recommendations from the 2010 National Heart, Lung and Blood Institute Workshop. Circulation. 2011;124(10):1172-1179.

35. Murry CE, Jennings RB, Reimer KA. Preconditioning with ischemia: a relay of lethal cell injury in ischemic myocardium. Circulation. 1986;74(5):1124-1136.

36. Hausenloy DJ, Yellon DM. Remote ischemic preconditioning: Underlying mechanisms and clinical application. Cardiovasc Res. 2008;79(3):377-386.

37. Botker HE, Kharbanda R, Schmidt MR, et al. Remote ischemic conditioning before hospital admission, as a complement to angioplasty, and effect on myocardial salvage in patients with acute myocardial infarction: a randomized trial. Lancet. 2010;375(9716):727-734.

38. Zhao ZQ, Corvera JS, Halkos ME, et al. Inhibition of myocardial injury by ischemic postconditioning during reperfusion: Comparison with ischemic preconditioning. Am J Physiol Heart Circ Physiol. 2003;285(2):H579-H588

39. Kerendi F, Kin H, Halkos ME, et al. Remote postconditioning: brief renal ischemia and reperfusion applied before coronary artery reperfusion reduces myocardial infarct size via endogenous activation of adenosine receptors. Basic Res Cardiol. 2005;100(5):404-412.

40. Sarmento-Leite R, Krepsky AM, Gottschall CA. Acute myocardial infarction. One century of history. Arq Bras Cardiol. 2001;77(6):593-610.

41. Salloum J, Tharpe C, Vaughan D, et al. Release and elimination of soluble vasoactive factors during percutaneous coronary intervention of saphenous vein grafts: analysis using the PercuSurge GuardWire distal protection device. J Invasive Cardiol. 2005;17(11):575-579.

42. Kunadian B, Dunning J, Vijayalakshmi K, et al. Meta-analysis of randomized trials comparing anti-embolic devices with standard PCI for improving myocardial reperfusion in patients with acute myocardial infarction. Catheter Cardiovasc Interv. 2007;69(4):488-496.

43. Vlaar PJ, Svilaas T, van der Horst IC Diercks GF, et al. Cardiac death and reinfarction after 1 year in the Thrombus Aspiration during Percutaneous coronary intervention in Acute myocardial infarction Study (TAPAS): a 1-year follow-up study. Lancet. 2008;371(9628):1915-1920.

44. Brodie BR. Aspiration thrombectomy with primary PCI for STEMI: review of the data and current guidelines. $J$ Invasive Cardiol. 2010;22(10Suppl B):2B-5B.

45. Griffiths EJ, Halestrap AP. Protection by Cyclosporin A of ischemia/ reperfusion-induced damage in isolated rat hearts. $J$ Mol Cell Cardiol. 1993;25(12):1461-1469.

46. Piot C, Croisille P, Staat P, et al. Effect of cyclosporine on reperfusion injury in acute myocardial infarction. $N$ Engl $\mathrm{J} \mathrm{Med}$. 2008;359(5):473-481.

47. Cung TT, Morel O, Cayla G, et al. Cyclosporine before PCI in Patients with Acute Myocardial Infarction. N Engl J Med. 2015;373(11):1021-1031.

48. Ottani F, Latini R, Staszewsky L, et al. Cyclosporine A in Reperfused Myocardial Infarction: The Multicenter, Controlled, Open-Label CYCLE Trial. J Am Coll Cardiol. 2016; 67(4):365-374.

49. Yang XM, Philipp S, Downey JM, et al. Atrial natriuretic peptide administered just prior to reperfusion limits infarction in rabbit hearts. Basic Res Cardiol. 2006;101(4):311-318.
50. Kitakaze M, Asakura M, Kim J Shintani Y, et al. Human atrial natriuretic peptide and nicorandil as adjuncts to reperfusion treatment for acute myocardial infarction (J-WIND): two randomised trials. Lancet. 2007;370(9597):1483-1493.

51. Miura T, Miki T. Limitation of myocardial infarct size in the clinical setting: current status and challenges in translating animal experiments into clinical therapy. Basic Res Cardiol. 2008;103(6):501-513.

52. Bulluck M, Yellon DM, Hausenloy DJ. Reducing myocardial infarct size: challenges and future opportunities. Heart. 2016;102(5):341-348.

53. Shandling AH, Ellestad MH, Hart GB, et al. Hyperbaric oxygen and thrombolysis in myocardial infarction. The Hot MI Pilot Study. Am Heart J. 1997;134(3):544-550

54. Beltrami AP, Urbanek K, Kajstura J, et al. Evidence that human cardiac myocytes divide after myocardial infarction. $N$ Engl J Med 2001;344(23):1750-1757.

55. Hierlihy AM, Seale P, Lobe CG, et al. The post-natal heart contains a myocardial stem cell population. FEBS Lett. 2002;530(1-3):239-243.

56. Quaini F, Urbanek K, Beltrami AP, et al. Chimerism of the transplanted heart. $N$ Engl J Med. 2002;346(1):5-15.

57. Orlic D, Kajstura J, Chimenti S, et al. Bone marrow cells regenerate infarcted myocardium. Nature. 2001;410(6829):701-705.

58. Jackson KA, Majka SM, Wang H, et al. Regeneration of ischemic cardiac muscle and vascular endothelium by adult stem cells. J Clin Invest. 2001;107(11):1395-1402.

59. Kocher AA, Schuster MD, Szabolcs MJ, et al. Neovascularization of ischemic myocardium by human bone-marrow-derived angioblasts prevents cardiomyocyte apoptosis, reduces remodeling and improves cardiac function. Nat Med. 2001;7(4):430-436

60. Strauer BE, Brehm M, Zeus T, et al. Repair of infarcted myocardium by autologous intracoronary mononuclear bone marrow cell transplantation in humans. Circulation. 2002;106(15):1913-1918.

61. Gulati R, Simari R. Cell Therapy for acute myocardial infarction. Med Clin North Am. 2007;91(4):769-785.

62. Shah VK, Tanavde V, Desai AJ, et al. Bone marrow cells for myocardial repair- a new therapeutic concept. Indian Heart J . 2007;59(6):482-490.

63. Shah VK, Shalia KK. Stem Cell Therapy in Acute Myocardial Infarction: A Pot of Gold or Pandora's Box, Stem Cells International. 2011;2011:536758.

64. Abdel-Latif A, Bolli R, Tleyjeh IM, et al. Adult bone marrow-derived cells for cardiac repair: a systematic review and meta-analysis. Arch Intern Med. 2007;167(10):989-997.

65. Leistner DM, Fischer-Rasokat U, Honold J, et al. Transplantation of progenitor cells and regeneration enhancement in acute myocardial infarction (TOPCARE-AMI): final 5-year results suggest long-term safety and efficacy. Clin Res Cardiol. 2011;100(10):925-934.

66. Moccetti T, Sürder D, Klersy C, et al. Sustained improvement in left ventricular function after bone marrow derived cell therapy in patients with acute ST elevation myocardial infarction. A 5-year follow-up from the Stem Cell Transplantation in Ischaemic Myocardium Study. Swiss Med Wkly. 2012;142:w13632.

67. Shah VK, Shalia KK. Stem Cell Therapy for Acute Myocardial Infarction-Long Term 24 Months Follow-Up. J Clin Trial Cardiol. 2014;1(2):1-5

68. Afzal MR, Samanta A, Shah ZI, et al. Adult Bone Marrow Cell Therapy for Ischemic Heart Disease: Evidence and Insights From Randomized Controlled Trials. Circ Res . 2015;117(6):558-575.

69. Karpov AA, Drahova AV, Buslova DV, et al. Modification of mesenchymal stem cells as a way to improve the effectiveness of cell therapy of ischemic myocardial injury. Ross Fiziol Zh Im I M Sechenova. 2015;101(9):985-998. 
70. Gao LR, Chen Y, Zhang NK, et al. Intracoronary infusion of Wharton's jelly-derived mesenchymal stem cells in acute myocardial infarction: double-blind, randomized controlled trial. BMC Med. 2015;13:162.

71. Musialek P, Mazurek A, Jarocha D, et al. Myocardial regeneration strategy using Wharton's jelly mesenchymal stem cells as an off-theshelf 'unlimited' therapeutic agent: results from the Acute Myocardial Infarction First-in-Man Study. Postepy Kardiol Interwencyjnej. 2015;11(2):100-107.

72. Hong KU, Bolli R. Cardiac stem cell therapy for cardiac repair. Curr Treat Options Cardiovasc Med . 2014;16(7):324.

73. Bolli R, Chugh AR, D'Amario D, et al. Cardiac stem cells in patients with ischaemic cardiomyopathy (SCIPIO): initial results of a randomised phase 1 trial. Lancet. 2011;378(9806):1847-1857.

74. Marbán E. Breakthroughs in cell therapy for heart disease: focus on cardiosphere-derived cells. Mayo Clin Proc. 2014;89(6):850-858.

75. Malliaras K, Makkar RR, Smith RR, et al. Intracoronary cardiospherederived cells after myocardial infarction: evidence of therapeutic regeneration in the final 1 -year results of the CADUCEUS trial (CArdiosphere-Derived aUtologous stem CElls to reverse ventricUlar dySfunction). J Am Coll Cardiol. 2014;63(2):110-122.

76. Martin U. New muscle for old hearts: engineering tissue from pluripotent stem cells. Hum Gene Ther . 2015;26(5):305-311.

77. Iyer D, Gambardella L, Bernard WG, et al. Robust derivation of epicardium and its differentiated smooth muscle cell progeny from human pluripotent stem cells. Development. 2015;142(8):1528-1541.

78. Thavandiran N, Dubois N, Mikryukov A, et al. Design and formulation of functional pluripotent stem cell-derived cardiac microtissues. Proc Natl Acad Sci U S A. 2013; 110(49):E4698-4707.

79. Soler-Botija C, Bago' JR, Bayes-Genis A. A bird's-eye view of cell therapy and tissue engineering for cardiac regeneration. Ann N Y Acad Sci. 2012;1254:57-65.

80. Liu B, Duan CY, Luo CF, et al. Impact of Timing following Acute Myocardial Infarction on Efficacy and Safety of Bone Marrow Stem Cells Therapy: A Network Meta-Analysis. Stem Cells Int 2016;2016:1031794.
81. Vunjak-Novakovic G, Tandon N, Godier A, et al. Challenges in cardiac tissue engineering. Tissue Eng Part B Rev. 2010;16(2):169-187.

82. Ga'lvez-Monto'n C, Prat-Vidal C, Roura S, et al. Transposition of a pericardial-derived vascular adipose flap for myocardial salvage after infarct. Cardiovasc Res. 2011; 91(4):659-667.

83. Chen J, Guo R, Zhou Q, et al. Injection of composite with bone marrowderived mesenchymal stem cells and a novel synthetic hydrogel after myocardial infarction: a protective role in left ventricle function. Kaohsiung J Med Sci. 2014;30(4):173-180.

84. Atluri P, Miller JS, Emery RJ, et al. Tissue-engineered, hydrogel-based endothelial progenitor cell therapy robustly revascularizes ischemic myocardium and preserves ventricular function. J Thorac Cardiovasc Surg. 2014;148(3):1090-1097.

85. Sepantafar M, Maheronnaghsh R, Mohammadi H Rajabi-Zeleti S, et al. Stem cells and injectable hydrogels: Synergistic therapeutics in myocardial repair. Biotechnol Adv. 2016;34(4):362-379.

86. Ishikawa K, Tilemann L, Fish K, et al. Gene delivery methods in cardiac gene therapy. J Gene Med. 2011;13(10):566-572.

87. Bayes-Genis A, Ga'lvez-Monto'n C, Prat-Vidal C, et al. Cardiac adipose tissue: a new frontier for cardiac regeneration? Int $J$ Cardiol. 2012;167(1):22-25.

88. Fujii $\mathrm{H}, \mathrm{Li} \mathrm{SH}, \mathrm{Wu} \mathrm{J}$, et al. Repeated and targeted transfer of angiogenic plasmids into the infarcted rat heart via ultrasound targeted microbubble destruction enhances cardiac repair. Eur Heart J. 2011;32(16):2075-2084.

89. Jessup M, Greenberg B, Mancini D, et al. Calcium Upregulation by Percutaneous Administration of Gene Therapy in Cardiac Disease (CUPID): a phase 2 trial of intracoronary gene therapy of sarcoplasmic reticulum $\mathrm{Ca} 2+$-ATPase in patients with advanced heart failure. Circulation. 2011;124(3):304-313.

90. Yang ZJ, Zhang YR, Chen B, et al. Phase I clinical trial on intracoronary administration of Ad-hHGF treating severe coronary artery disease. $\mathrm{Mol}$ Biol Rep. 2009;36(6):1323-1329. 